\title{
Penerapan Metode Profile Matching pada Perekrutan Karyawan untuk PT. Dinasti Motekar Group
}

\author{
Dedi Liyus Mardi \\ Jurusan Sistem Informasi, STMIK LIKMI, Bandung, Indonesia \\ dediliyusmardi@gmail.com
}

Diterima 10 April 2020

Disetujui 15 Juni 2021

\begin{abstract}
Human resources are particularly important factor in any corporation to support the successful corporation. Employee recruitment is a thing that is not separated from a human resources management activity. To have employee fit expectation of corporation, the right employee recruitment system is necessary to have employee in accordance with his or her expertise. In the process of employee recruitment, a supporting decision system is required. Method used to make the employee recruitment system is using Profile Matching. In this study is raised a cases; i.e. seeking for the best alternative for the recruitment of employee in PT. Dinasti Motekar Group. The Profile Matching was chosen as it can establish weight grade for each attribute, then it is continued by the ranking process to be able to select the best alternative from other alternatives. The best alternative, therefore, might be acquired based on specific criteria as they were established by the corporation.
\end{abstract}

Index Terms-decision support system, employee recruitment; profile matching

\section{PENDAhUluan}

Perkembangan Teknologi Informasi saat ini telah memungkinkan untuk pengambilan keputusan yang dapat dilakukan dengan lebih cepat, akurat dan mudah. Penggunaan komputer pada saat ini telah berkembang bukan untuk sekedar pengolahan data tetapi memberikan penyajian informasi yang baik dan mampu untuk menyediakan pilihan sebagai pendukung untuk mengambil sebuah keputusan.

Dalam suatu perusahaan, karyawan merupakan salah satu kunci penting dalam mencapai tujuan perusahaan. Namun untuk memperoleh karyawan yang tepat sesuai dengan harapan perusahaan tentu tidaklah mudah.

Sering kali kita mendapati karyawan yang baru masuk kedalam suatu perusahaan hanya bertahan dalam jangka waktu yang pendek saja. Alasan yang utama adalah kesalahan perekrutan karyawan baru. Setelah melakukan perekrutan ternyata karyawan tersebut tidak memiliki kemampuan dalam bidang pekerjaan tersebut maupun tidak mempunyai kualifikasi atau kriteria yang dibutuhkan oleh pihak perusahaan tersebut.

Sistem dalam melakukan perekrutan karyawan pada saat ini masih menggunakan secara manual. Penentuan bagaimana untuk mendapatkan kriteriakriteria dan syarat-syarat ketika dalam melakukan perekrutan karyawan masih dilakukan secara manualisasi. Kemampuan komputer dalam menyelesaikan masalah ini dapat dilakukan dengan menggunakan suatu Sistem Pendukung Keputusan (SPK) atau bisa juga disebut Decission Support System (DSS).

Dari permasalahan di atas, maka akan dibangun suatu sistem pendukung keputusan untuk perekrutan karyawan baru pada PT. Dinasti Motekar Grup. Sistem pendukung keputusan ini akan dibangun dengan menggunakan metode pengambilan keputusan metode Profile Matching.

Profile Matching merupakan metode yang tepat digunakan dalam proses membandingkan antar kompetensi karyawan ke dalam potensi suatu jabatan yang dibutuhkan oleh pihak perusahaan sehingga dapat diketahui perbedaan kompetensinya antara kompetensi karyawan dan kompetensi sebuah jabatan dengan pembobotan dan perhitungan gap untuk calon karyawan yang memiliki gap lebih kecil maka nilai bobotnya akan semakin besar.

Metode Profile Matching digunakan karena kemampuan untuk melakukan penilaian secara lebih tepat sebab didasarkan pada kriteria dan bobot yang telah ditentukan, serta akan lebih efisien dalam melakukan perekrutan karyawan karena waktu yang dibutuhkan dalam melakukan akan perhitungan lebih singkat dan tepat. kesimpulan bahwa proses penilaian perekrutan karyawan pada perusahaan tersebut belum dilakukan secara efektif dan efisien, sehingga perlu adanya sistem yang baru agar mempermudah dalam pengambilan keputusan. Metode tersebut berhasil diterapkan pada suatu penilaian di perusahaan.

Berdasarkan latar belakang permasalahan akan kebutuhan atas suatu sistem pendukung, maka 
penelitian tentang rancang bangun sistem pendukung keputusan perekrutan karyawan baru dengan metode Profile Matching ini dilakukan.

\section{LANDASAN TEORI}

\section{A. Seleksi Karyawan}

Seleksi karyawan sebuah pelamar yang sudah diperoleh melalui berbagai dari kegiatan rekrutmen pada proses selanjutnya untuk melanjuti tahap seleksi, pada tahap seleksi karyawan adalah proses yang terdiri dari berbagai tahapan-tahapan sehingga dapat diambil kesimpulan dan memutuskan apakah pelamar tersebut diterima atau tidak diterima [1].

\section{B. Sistem Pendukung Keputusan}

SPK merupakan sistem informasi yang berbasis komputer yang fleksibel, interaktif dan dapat diadaptasi, yang dikembangkan untuk mendukung solusi untuk masalah manajemen spesifik yang tidak terstruktur menggunakan data memberikan antarmuka pengguna yang mudah dan dapat menggabungkan pemikiran pengambilan keputusan [2].

Sistem pendukung keputusan adalah bagian dari suatu sistem informasi yang telah digunakan untuk pengambilan keputusan. Sistem pendukung keputusan digunakan oleh suatu perusahaan sebagai bahan pertimbangan untuk melakukan sesuatu dalam. SPK juga dapat diartikan sebagai suatu sistem informasi yang ditunjukan untuk membantu manajemen perusahaan dalam mengambil keputusan yang berkaitan dengan persoalan dalam mecari karyawan yang bersifat terstruktur (hukum sebab-akibat dari adanya suatu variabel belum pasti atau bukan suatu rutinitas) [3].

Sistem pendukung keputusan definisikan sebagai sistem memiliki kemampuan dalam menyelesaikan suatu masalah semi terstruktur. Sedangkan definisi dari sistem pendukung keputusan secara khusus yaitu sistem diperuntukan untuk manajer maupun sekelompok manajer dalam suatu perusahaan dalam memecahkan masalah dengan cara memberikan usulan menuju pada keputusan tertentu [4].

\section{Metode Profile Matching}

Profile matching merupakan suatu proses yang sangat penting dalam manajemen SDM dimana terlebih dahulu ditentukan kompetensi (kemampuan) yang diperlukan oleh suatu jabatan. Kompetensi atau kemampuan tersebut haruslah dapat dipenuhi oleh pemegang atau calon pemegang jabatan. Dalam proses profile matching secara garis besar merupakan proses membandingkan antara kompetensi individu kedalam kompetensi jabatan sehingga dapat diketahui perbedaan kompetensinya (disebut juga Gap), semakin kecil gap yang dihasilkan maka bobot nilainya semakin besar yang berarti memiliki peluang lebih besar untuk pegawai yang menempati posisi tersebut [5]. Profile Matching adalah sebuah metode yang bertujuan untuk mengambil keputusan dengan mengasumsikan bahwa terdapat tingkat variabel prediktor yang ideal yang harus dipenuhi oleh subyek yang diteliti, bukannya tingkat minimal yang harus dipenuhi atau dilewati [6].

Profile Matching adalah sebuah dalam mekanisme pengambilan suatu keputusan dengan mengasumsikan bahwa terdapat tingkat minimal yang harus dipenuhi atau dilewati. [7]

Berikut ini adalah beberapa tahapan dan perhitungan dengan metode profile matching:

1. Pembobotan: Pada bagian ini, akan ditentukan untuk bobot nilai dari masing-masing dari aspek dengan bobot nilai dari aspek yang telah ditentukan dari masing-masing aspek kebutuhan. Setelah diperoleh gap pada masing-masing karyawan, setiap profil karyawan diberi bobot nilai sesuai ketentuan seperti Tabel 1.

Tabel 1. Bobot nilai gap

\begin{tabular}{|c|c|c|c|}
\hline No & $\begin{array}{l}\text { Selisih } \\
\text { Gap }\end{array}$ & $\begin{array}{l}\text { Bobot } \\
\text { Nilai }\end{array}$ & Keterangan \\
\hline 1 & $\mathbf{0}$ & 5 & $\begin{array}{l}\text { Kompetensi sesuai } \\
\text { dengan yang dibutuhkan }\end{array}$ \\
\hline 2 & 1 & 4,5 & $\begin{array}{l}\text { Kompetensi individu } \\
\text { kelebihan } 1 \text { tingkat } \\
\text { /level }\end{array}$ \\
\hline 3 & -1 & 4 & $\begin{array}{l}\text { Kompetensi individu } \\
\text { kurang } 1 \text { tingkat/level }\end{array}$ \\
\hline No & $\begin{array}{c}\text { Selisih } \\
\text { Gap }\end{array}$ & $\begin{array}{l}\text { Bobot } \\
\text { Nilai }\end{array}$ & Keterangan \\
\hline 4 & 2 & 3,5 & $\begin{array}{l}\text { Kompetensi individu } \\
\text { kelebihan } 2 \text { tingkat/level }\end{array}$ \\
\hline 5 & -2 & 3 & $\begin{array}{l}\text { Kompetensi individu } \\
\text { kurang } 2 \text { tingkat/level }\end{array}$ \\
\hline 6 & 3 & 2,5 & $\begin{array}{l}\text { Kompetensi individu } \\
\text { kelebihan } 3 \text { tingkat/level }\end{array}$ \\
\hline 7 & -3 & 2 & $\begin{array}{l}\text { Kompetensi individu } \\
\text { kurang } 3 \text { tingkat/level }\end{array}$ \\
\hline 8 & 4 & 1,5 & $\begin{array}{l}\text { Kompetensi individu } \\
\text { kelebihan } 4 \text { tingkat } \\
\text { /level }\end{array}$ \\
\hline 9 & -4 & 1 & $\begin{array}{l}\text { Kompetensi individu } \\
\text { kurang } 4 \text { tingkat /level }\end{array}$ \\
\hline
\end{tabular}

2. Pengelompokan Core Factor dan Secondary Factor. Pada bagian ini akan melakukan penentuan suatu bobot nilai gap untuk kriteria yang di telah butuhkan, kemudian setiap dari kriteria akan menjadi kriteria core factor dan kriteria secondary factor.

a. Core factor

Core factor ialah aspek yang sangat menonjol dan dibutuhkan oleh suatu posisi yang dapat 
menghasilkan yang terbaik. Untuk menghitung core factor akan digunakan rumus:

$$
N C F=\frac{\sum N C}{\sum I C}
$$

b. Secondary factor

Untuk menghitung secondary factor digunakan rumus:

$$
N S F=\frac{\sum N S}{\sum I S}
$$

3. Penghitungan Nilai Total. Dari perhitungan core factor dan secondary factor maka akan dilakukan hitungan nilai total dari setiap aspek yang dipekirakan sangat berpengaruh pada kinerja setiap profil. Rumus untuk menghitung nilai total adalah:

$$
\mathrm{N}=(\mathrm{X}) \% \mathrm{NCF}+(\mathrm{X}) \% \mathrm{NSF}
$$

4. Perangkingan. Dari hasil akhir proses profile matching adalah akan dilakukam perangkingan penentuannya akan mengacu dari rangking pada hasil perhitung yang telah ditunjukkan oleh rumus:

$$
\text { Rangking }=70 \% \mathrm{NCF}+30 \%
$$

\section{Kriteria SPK Perekrutan Karyawan}

Ada Beberapa kriteria-kriteria pada sistem perekrutan karyawan di PT. Motekar Group sebagai berikut:

1. Pendidkan, merupakan yang penting dalam suatu perusahaan,dengan ukuran bobot pada Tabel 2 .

Tabel 2. Kriteria pendidikan

\begin{tabular}{|c|c|}
\hline Nilai & Bobot \\
\hline S1 & 2 \\
\hline D3 & 1 \\
\hline
\end{tabular}

2. Jurusan, yang sesuai dengan penempatan jabatan, dengan ukuran bobot pada Tabel 3 .

Tabel 3. Kriteria jurusan

\begin{tabular}{|c|c|}
\hline Nilai & Bobot \\
\hline Akuntansi & 3 \\
\hline Manajemen & 2 \\
\hline Umum & 1 \\
\hline
\end{tabular}

3. Usia, sangat penting karena perusahaan berjalan secara efisien demi keberlangsungan hidup banyak karyawan di dalamnya, dengan ukuran bobot pada Tabel 4.
Tabel 4. Kriteria usia

\begin{tabular}{|c|c|}
\hline Nilai & Bobot \\
\hline $22-35$ & 2 \\
\hline $36-45$ & 1 \\
\hline
\end{tabular}

4. Pengalaman, kebanyakan dari perusahaan melihat pengalaman calon karyawan tersebut berapa lama dia bekerja, dengan ukuran bobot pada Tabel 5 .

Tabel 5. Kriteria pengalaman

\begin{tabular}{|c|c|}
\hline Nilai & Bobot \\
\hline 2 Tahun & 3 \\
\hline 1 Tahun & 2 \\
\hline Belum & 1 \\
\hline
\end{tabular}

5. Test Pengetahuan, untuk menguji kemampuan calon setiap karyawan, dengan ukuran bobot pada Tabel 6.

Tabel 6. Kriteria pengetahuan

\begin{tabular}{|c|c|}
\hline Nilai & Bobot \\
\hline $82-100$ & 5 \\
\hline $62-80$ & 4 \\
\hline $42-60$ & 3 \\
\hline $22-40$ & 2 \\
\hline $0-20$ & 1 \\
\hline
\end{tabular}

6. Keahlian, untuk menguji keahlian jabatan yang diinginkan calon karyawan. Karakter, untuk melihat penilaian terhadap dari karakter masingmasing karyawan. Penampilan, untuk melihat penilaian terhadap masing-masing karyawan, Wawancara, untuk melihat penilaian terhadap hasil wawancara karywan. Dengan ukuran bobot pada Tabel 7.

Tabel 7. Kriteria keahlian, karakter, penampilan wawancara

\begin{tabular}{|c|c|}
\hline Nilai & Bobot \\
\hline A & 5 \\
\hline B & 4 \\
\hline C & 3 \\
\hline D & 2 \\
\hline E & 1 \\
\hline
\end{tabular}

\section{E. Rational Unified Process (RUP)}

Rational Unified Process merupakan suatu pendekatan dari sebuah pengembangan pada perangkat lunak dengan dilakukan secara berulang ulang, fokus pada arsitektur yang baru dikembangkan, lebih pada diarahkan berbagai dari penggunaan kasus. RUP merupakan proses dari rekayasa pada perangkat lunak dengan maksud pendefinisian secara baik dan terstruktur dengan baik [8].

Tujuan dari RUP adalah menghasilkan suatu perangkat lunak yang berkualitas tinggi yang dapat memenuhi kebutuhan pengguna [9]. 
RUP adalah salah satu pengembangan untuk perangkat lunak yang berbasis UML mempunyai tahap-tahap sebagai berikut:

1. Permulaan (inception). Tahapan ini dimulai dengan studi pendahuluan dan pengumpulan data yang ada di PT. Dinasti Motekar. Setelah itu dilakukan analisis terhadap kebutuhan sistem yaitu kebutuhan yang diinginkan dan diperlukan oleh pengguna. Data untuk analisis didapatkan melalui 3 cara yaitu wawancara, observasi, dan analisis dokumen. Setelah melakukan tiga proses tersebut akan dilakukan proses pengecekan untuk mengecek perubahan terhadap suatu analisis tersebut. Dalam melakukan pengecekan terhadap hasil wawancara akan dibuat beberapa pertanyaan yang akan dibuatkan dalam form pelaporan dari hasil-hasil pertanyaan dari perusahaan tersebut. Berdasarkan hasil dari analisis sistem yang sedang berjalan usulan sistem yang baru menggunakan diagram untuk menggambarkan ruang lingkup pada suatu sistem yang akan dibuat

2. Pemerincian (elaboration). Pada tahap ini akan dilakukan perancangan sistem. Pada tahap ini merupakan tahap lanjutan dari inception, pada tahap ini akan dilakukan perancangan terhadap sistem yang akan dibuat berdasarkan hasil tahapan inception. Tahap ini mengubah kebutuhan perangkat lunak ke desain untuk dapat diterjemahkan ke dalam program.

3. Konstruksi (construction). Tahap ini pembuatan coding setelah tahapan elaboration selesai dan mengubah dari desain sistem ke dalam program dengan menggunakan konsep dari Object Oriented Programing Pembuatan aplikasi ini menggunakan bahasa pemrograman PHP dengan mengunakan internet dan menggunakan database MySql.

4. Transisi (transition). Pengujian logika dan fungsional perangkat lunak dilakukan pada tahap ini agar tidak terdapat error yang ada pada perangkat lunak sehingga sistem dapat berjalan seperti yang diharapkan [10].

\section{F. Unified Modelling Language (UML)}

Unified Modelling Language adalah bahasa spesifikasi standar yang dipergunakan untuk dokumentasikan, menspesifikasikan dan membanngun perangkat lunak. UML merupakan metodologi dalam mengembangkan sistem berorientasi objek dan juga merupakan alat untuk mendukung pengembangan sistem [11].

UML (Unified Modelling Language) merupakan salah satu standar bahasa yang digunakan di dunia industri untuk mendefenisikan requirement, membuat analisis dan desain, serta menggambarkan arsitektur dalam pemrograman berorientasi objek [12].
Sistem informasi yang akan dibuat, UML menyediakan beberapa diagram diantanya sebagai berikut:

- Use Case Diagram merupakan teknik dalam menggambarkan sebuah sistem informasi untuk keperluan fungsional dari sebuah sistem yang akan dibangun.

- Activity Diagram adalah aliran cara kerja dengan menggambarkan proses bisnis atau sistem.

- Conceptual Data Model merupakan rancangan suatu database sesuai dengan hasil analisis dan pengumpulan data[13].

UML ialah bahasa pemodelan yang dapat memberikan secara terperinci sehingga dapat menganalisa apa yang diperlukan oleh membangun sebuah sistem.

\section{Metodologi Peneltian}

Metode penelitian pada dasarnya merupakan cara ilmiah untuk mendapatkan data dengan tujuan dan kegunaan tertentu. Metode ialah suatu kerangka kerja untuk melakukan suatu tindakan, atau suatu kerangka berfikir menyusun gagasan, yang beraturan, berarah data berkonteks, yang (relevant) dengan maksud dan tujuan. Secara ringkas, metode ialah suatu sistem berbuat. Karena berupa sistem maka metode merupakan seperangkat unsur-unsur yang membentuk suatu kesatuan [14].

Sistem pendukung pengambilan keputusan yang membantu PT. Dinasti Motekar Group dalam menentukan pilihan terbaik dalam penerimaan karyawan baru pada suatu perusahaan yang berdasarkan kriteria yang telah ditentukan oleh perusahaan untuk penyeleksian karyawan baru.

Kriteria yang akan digunakan adalah Pendidikan, jurusan, pengalaman, test pengetahuan, test keahlian, karakter, penampilan, usia dan wawancara dari karyawan berdasarkan bobot yang sudah ditentukan oleh perusahaan.

\section{A. Tahap Perencanaan}

Pada Tahap ini penulis melakukan perencanaan tentang tujuan dibentuknya sistem pendukung pengambilan keputusan, sehingga akan lebih mudah untuk menentukan metode apa yang akan digunakan. Langkah awal adalah mempelajari kebutuhan sistem serta kriteria yang akan menjadi acuan dibentuknya sistem pendukung pengambilan keputusan.

1. Observasi. merupakan salah satu metode dalam pengumpulan data yang melakukan pengamatan atau peninjauan langsung untuk mencari data-data yang dibutuhkan sesuai dengan permasalahannya 
yaitu membangun sistem sebagai pendukung keputusan. Sistem Pendukung keputusan pada pemilihan karyawan baru yang berbasis web dengan menerapkan metode profile matching agar memperoleh data-data dan informasi yang akurat. Kegiatan pengamatan langsung ini dilakukan di bawah pengawasan Direktur Utama dari PT.Dinasti Motekar Group Bandung, Jawa Barat. Beliau memberikan data bagaimana menerima karyawan baru dan prosedur- prosedur yang harus dipenuhi calon karyawan.

2. Studi Pustaka. Pada tahap ini penulis mencari referensi dari berbagai sumber yang mendukung dalam pengerjaan sistem pendukung pengambilan keputusan penerimaan karyawan baru dan mempelajari teori- teori yang terdapat dalam jurnal dari metode profile matching dalam sebuah sistem pendukung pengambilan keputusan. Sumber yang didapat sebagai referensi berasal dari jurnal nasional/ internasional, situs-situs penunjang, serta buku-buku yang berkaitan dengan sistem pendukung keputusan peyeleksian karyawan untuk perusahaan.

3. Wawancara. Wawancara dilakukan dengan mengadakan tanya jawab dengan Acep Hendra, ST., C.Ht., selaku Direktur Utama. Untuk memperoleh data-data yang diperlukan dalam perancangan dan pembuatan sistem pendukung keputusan pada PT.Dinasti Motekar Group Bandung, Jawa Barat. Selain itu, wawancara juga dilakukan kepada kepada beberapa yang berada di sana. Melakukan wawancara (interview) kepada pihak-pihak terkait dengan cara berkomunikasi secara langsung untuk mengetahui informasiinformasi yang dibutuhkan seperti kriteria-kriteria untuk pemilihan karyawan baru untuk sebagai pendukung sebuah keputusan pemilihan karyawan baru menghasilkan urutan alternatif terbaik.

\section{B. Tahap Perencanaan Sistem}

Tahap pertama untuk pembuatan suatu program, yang pertama kali harus dilakukan adalah tahap perancangan, sebagai tolak ukur perancangan yang pertama kali harus dikemukakan terlebih dahulu adalah spesifikasi alat yang ingin dibuat secara tertulis. Dengan demikian hasil perancangan akan dijadikan acuan untuk pembuatan program, disamping itu dengan adanya tahap perancangan kemungkinankemungkinan yang dapat menghambat dalam pembuatan program dapat dihindari.

1. Permulaan (inception). Tahapan ini dimulai dengan studi pendahuluan dan pengumpulan data yang ada di PT. Dinasti Motekar. Setelah itu dilakukan analisis terhadap pengelolahan data dan informasi dari hasil pengumpulan data sehingga dapat dilakukan analisis terhadap sistem.Saat ini, kebanyakan tata cara pemilihan karyawan masih menggunakan metode lama yaitu sistem rekrutmen menggunakan hak prerogatif pimpinan atas dasar kebutuhan untuk setiap pekerjaan. Dengan adanya sistem baru yang akan di bangun dapat membantu perusahaan dalam pemilihan karyawan sesuai dengan kebutuhan kriteria yang akan di tentukan oleh pihak perusahaan dan mendapatkan pilihan terbaik.

2. Pemerincian (elaboration). Pada tahap ini akan dilakukan perancangan terhadap sistem yang akan dibuat berdasarkan hasil tahapan inception. Pada tahap elaboration ini penelitian dilakukan dengan membuat perancang system untuk Sistem Pendukung Keputusan pemilihan karyawan baru di PT.Dinasti Motekar Group. Perancangan tersebut terdiri dari perancangan database, arsitektur perangkat lunak, dan perancangan. Tahap ini mengubah kebutuhan perangkat lunak ke desain untuk dapat diterjemahkan ke dalam program.

3. Konstruksi (construction). Tahap ini pembuatan coding setelah tahapan elaboration selesai dan mengubah dari desain sistem ke dalam program dengan menggunakan konsep dari object oriented programing (OOP) .Pembuatan aplikasi ini menggunakan bahasa pemrograman PHP dengan mengunakan internet dan menggunakn database MySql menggunakan database MySql karena MySql merupakan database open source sehingga memudahkan untuk penggunaan.

4. Transisi (transition). Pengujian logika dan fungsional perangkat lunak dilakukan pada tahap ini agar tidak terdapat error yang ada pada perangkat lunak sehingga sistem dapat berjalan seperti yang diharapkan.

\section{HASIL DAN PEMBAHASAN}

A. Analisis dan Perhitungan Profile Matching

Nilai gap didapat dari selisih nilai calon profil karyawan dan profil kebutuhan dapat dirumuskan:

\section{GAP = Profil Karyawan - Profil Jabatan}

Yang dimaksud gap adalah selisih antara profil karyawan dengan profil jabatan. Pengumpulan gapgap yang terjadi pada tiap-tiap kriteria mempunyai perhitungan yang berbeda. Berikut adalah hasil selisih gap profil karyawan dengan profil jabatan seperti Tabel 8. 
Tabel 8. Hasil selisih nilai gap

\begin{tabular}{|c|c|c|c|c|c|c|c|c|c|c|}
\hline & & \multicolumn{9}{|c|}{ Jabatan } \\
\hline & Kriteri & $\mathrm{C} 1$ & $\mathrm{C} 2$ & $\mathrm{C} 3$ & $\mathrm{C} 4$ & $\mathrm{C} 5$ & C6 & $\mathrm{C} 7$ & $\mathrm{C} 8$ & $\mathrm{C} 9$ \\
\hline & $\begin{array}{c}\text { Profil } \\
\text { karyawan }\end{array}$ & 2 & 2 & 2 & 3 & 4 & 3 & 5 & 2 & 4 \\
\hline A1 & $\begin{array}{c}\text { Profil } \\
\text { Jabatan }\end{array}$ & 2 & 3 & 3 & 5 & 5 & 5 & 5 & 2 & 5 \\
\hline & Selisih gap & 0 & -1 & -1 & -2 & -1 & -2 & 0 & 0 & -1 \\
\hline & Kriteria & C1 & $\mathrm{C} 2$ & $\mathrm{C} 3$ & $\mathrm{C} 4$ & $\mathrm{C} 5$ & C6 & $\mathrm{C} 7$ & $\mathrm{C} 8$ & $\mathrm{C} 9$ \\
\hline & $\begin{array}{c}\text { Profil } \\
\text { karyawan }\end{array}$ & 2 & 2 & 2 & 4 & 4 & 3 & 3 & 2 & 4 \\
\hline A2 & $\begin{array}{c}\text { Profil } \\
\text { Jabatan }\end{array}$ & 2 & 3 & 3 & 5 & 5 & 5 & 5 & 2 & 5 \\
\hline & Selisih gap & 0 & -1 & -1 & -1 & -1 & -2 & -2 & 0 & -1 \\
\hline & Kriteria & $\mathrm{C} 1$ & $\mathrm{C} 2$ & C3 & $\mathrm{C} 4$ & $\mathrm{C} 5$ & C6 & $\mathrm{C7}$ & $\mathrm{C} 8$ & C9 \\
\hline & $\begin{array}{c}\text { Profil } \\
\text { karyawan }\end{array}$ & 2 & 3 & 3 & 5 & 4 & 5 & 5 & 2 & 5 \\
\hline A3 & $\begin{array}{c}\text { Profil } \\
\text { jabatan }\end{array}$ & 2 & 3 & 3 & 5 & 5 & 5 & 5 & 2 & 5 \\
\hline & Selisih gap & 0 & 0 & 0 & 0 & -1 & 0 & 0 & 0 & 0 \\
\hline
\end{tabular}

Setelah mendapati nilai selisih gap dari setiap kriteria penilaian, selanjutnya adalah konversikan gap tersebut kedalam bobot gap. Dimana masing-masing kriteria mempunyai bobot nilai gap yang berbeda-beda seperti Tabel 9.

Tabel 9. Bobot nilai gap

\begin{tabular}{|l|l|rrrrrrrrrr|}
\hline & & \multicolumn{10}{|c|}{ Jabatan } \\
\hline & Kriteria & & C1 & C2 & C3 & C4 & C5 & C6 & C7 & C8 & C9 \\
\hline 1 & Bobot gap & 5 & 4 & 4 & 3 & 3 & 4 & 5 & 5 & 4 \\
& Kriteria & C1 & C2 & C3 & C4 & C5 & C6 & C7 & C8 & C9 \\
\hline 2 & Bobot gap & 5 & 4 & 4 & 4 & 4 & 3 & 3 & 5 & 4 \\
& & Kriteria & C1 & C2 & C3 & C4 & C5 & C6 & C7 & C8 & C9 \\
\hline 3 & Bobot gap & 5 & 5 & 5 & 5 & 4 & 5 & 5 & 5 & 5 \\
\hline
\end{tabular}

Setelah melakukan pembobotan nilai gap, maka yang dilakukan selanjutnya adalah menghitung ratarata nilai kelompok kriteria Core Factor dan Secondary Factor :

Menghitung Kriteria Core Factor pada A1:

$\mathrm{NCF}=(5+4+4+3+5+4) / 6=4,1$

Menghitung Kriteria Core Factor pada A2:

$\mathrm{CF}=(5+4+4+4+5+4) / 6=4,3$

Menghitun Kriteria Core Factor pada A3:

$\mathrm{CF}=(4+3+5+4+5+5) / 6=4,8$

Menghitung Kriteria Secondary Factor pada A1:

$\mathrm{NSF}=(3+4+5) / 3=4$

Menghitung Kriteria Secondary Factor pada A2:

$\mathrm{NSF}=(4+3+3) / 3=3,33$

Menghitung Kriteria Secondary Factor pada A3:

$\mathrm{NSF}=(5+5+5) / 3=5$

Dari hasil perhitungan Core Factor dan Secondary Factor pada setiap jabatan, maka dapat terlihat pada Tabel 10.
Tabel 10. Pemetaan bobot nilai gap

\begin{tabular}{|c|c|c|}
\hline & \multicolumn{2}{|c|}{ Jabatan } \\
\hline & Core Factor & Secondary Factor \\
\hline A1 & 4.1 & 4 \\
\hline & Core Factor & Secondary Factor \\
\hline A2 & 4.3 & 3.33 \\
\hline & Core Factor & Secondary Factor \\
\hline A3 & 4.8 & \\
\hline
\end{tabular}

Setelah dapat nilai core factor dan secondary factor maka yang dilakukan selanjutnya adalah perhitungan nilai total dengan persentase core factor adalah $60 \%$ dan secondary factor adalah $40 \%$.

Menghitung nilai total pada A1:

$\mathrm{N}=(60 \% * 4.1)+(30 \% * 4)=3,66$

Menghitung nilai total pada A2:

$\mathrm{N}=(60 \% * 4.3)+(30 \% * 3.33)=3,57$

Menghitung nilai total pada A3:

$\mathrm{N}=(60 \% * 4.8)+(30 \% * 5)=4,38$

Dimana masing-masing calon karyawan baru mempunyai nilai total tertinggi hingga terendah seperti Tabel 11.

Tabel 10. Hasil akhir

\begin{tabular}{|c|c|c|c|c|}
\hline No & No Pendaftaran & Jabatan & Nilai & Rangking \\
\hline 1 & A1 & Accounting & 3.66 & 2 \\
\hline 2 & A2 & Accounting & 3.57 & 3 \\
\hline 3 & A3 & Accounting & 4.38 & 1 \\
\hline
\end{tabular}

\section{B. Analisis Tahap Perancangan Sistem}

\section{Use Case Diagram}

Diagram yang menggambarkan actor, use case dan relasinya suatu urutan atau tindakan yang memberikan nilai terukur untuk aktor. Use Case diagram biasanya dimiliki gambar elips horizontal dan orang. Elips berfungsi untuk mewakili suatu aktivitas, Sedangkan orang mewakili suatu jenis pengguna [15]. Use case melaporkan interaksi antara aktor di dalam sistem pendukung keputusan perekrutan karyawan baru di PT. Dinasti Motekar Group. Berikut adalah Use Case diagram sistem perekrutan karyawan baru di PT. Dinasti Motekar seperti Gambar 1. 


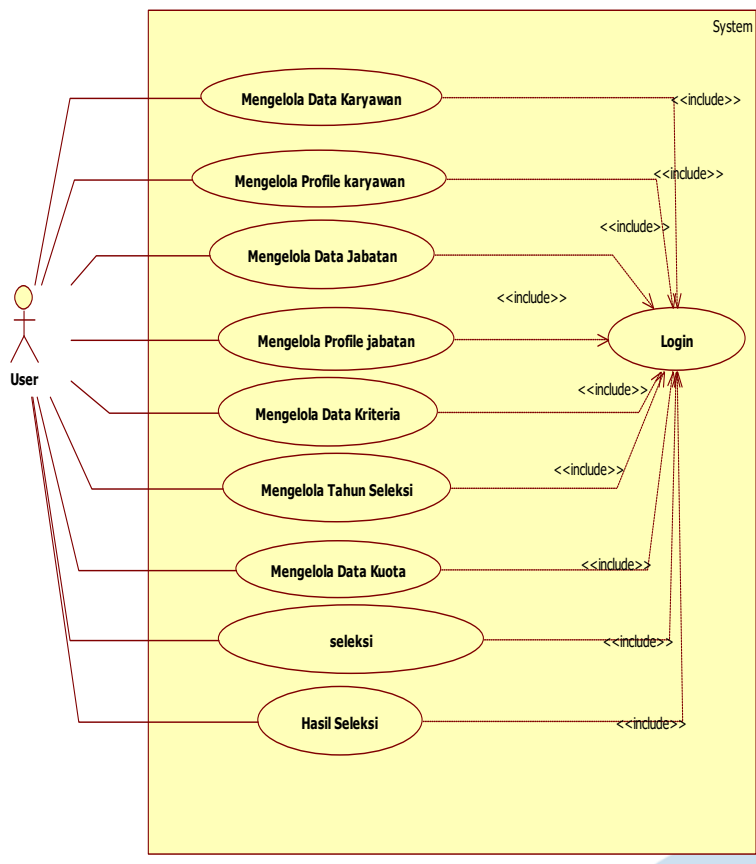

Gambar 1. Use Case diagram

\section{Activity Diagram}

Activity Diagram di bawah ini menjelaskan bagaimana user melakukan pengelolahan data terhadap data-data calon karyawan. Activity Diagram menu kelola data karyawan menyediakan halaman bagi admin untuk menambah, mengedit, dan mengahapus data karyawan seperti Gambar 2.

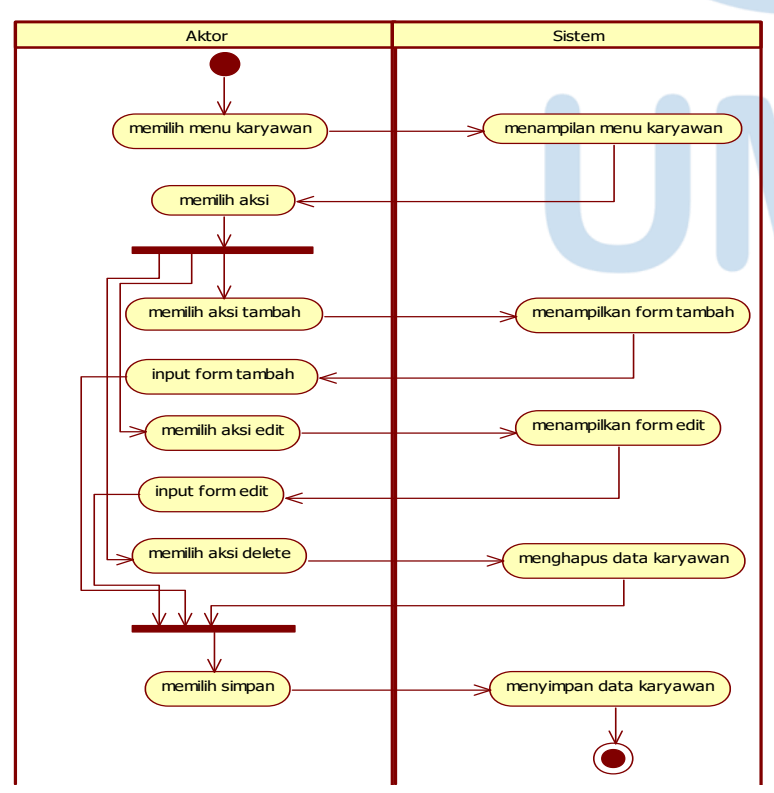

Gambar 2. Activity diagram

Activity Diagram di bawah ini menjelaskan bagaimana user melakukan pengelolahan data terhadap data kriteria. Activity Diagram menu kelola data kriteria menyediakan halaman bagi admin untuk menambah, mengedit, dan mengahapus data karyawan seperti Gambar 3.

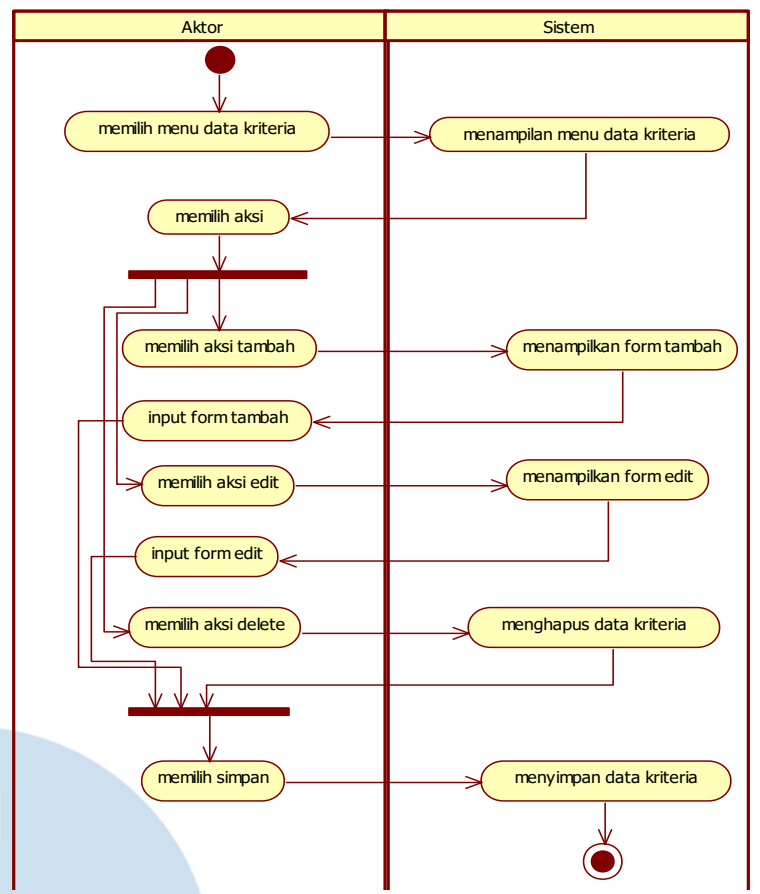

Gambar 3. Activity diagram data kriteria

Activity Diagram di bawah ini menjelaskan bagaimana user melakukan pengelolahan data terhadap data jabatan. Activity Diagram menu kelola data jabatan menyediakan halaman bagi admin untuk menambah, mengedit, dan mengahapus data karyawan. Untuk lebih jelasnya, dapat dilihat seperti Gambar 4 . 


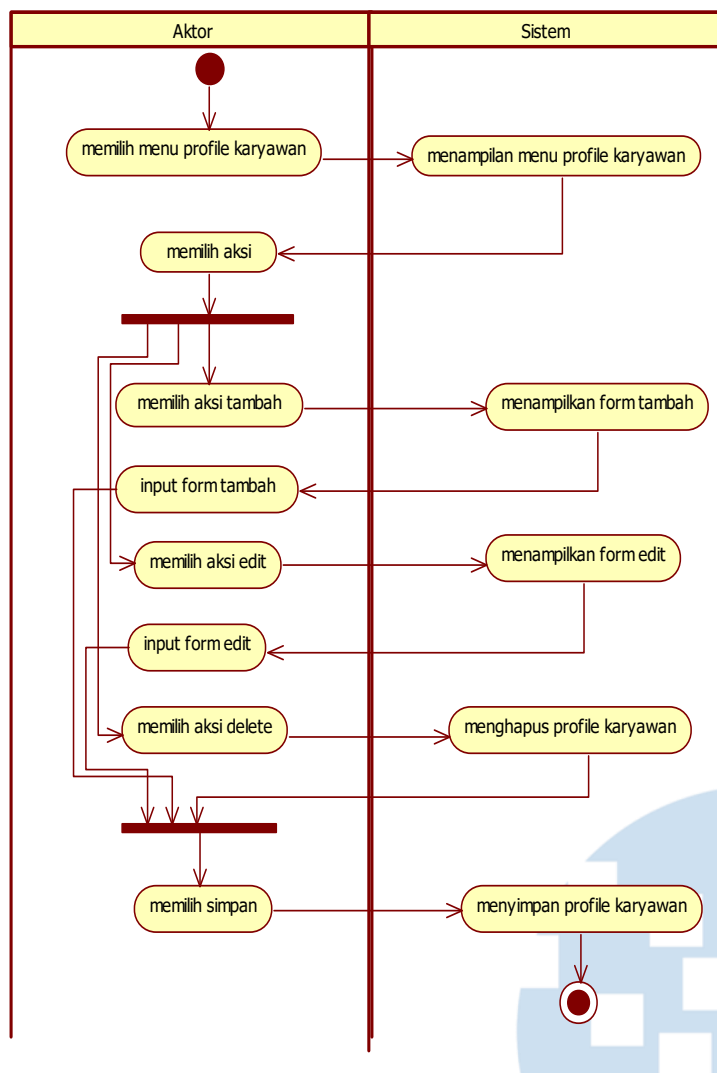

Gambar 4. Activity diagram data jabatan

\section{Sequence Diagram}

Sequence diagram data karyawan interasi pengguna dan sistem pada halaman data karyawan. Urutan kerja yang dilakukan oleh User dalam mengelola data-data karyawan. User yang telah berhasil masuk ke dalam halaman utama dapat memilih aksi tambah, edit, dan delete. Setelah dipilih aksi tambah dan edit, sistem akan menampilkan tampilan form untuk tambah dan edit. Form pada input tambah dan edit yang berisikan form data karyawan yang harus diisi oleh User. Setelah diisi dengan benar, data disimpan. User memilih aksi delete maka datadata karyawan akan terhapus Detail proses sequence diagram kelola data karyawan dapat dilihat pada Gambar 5.

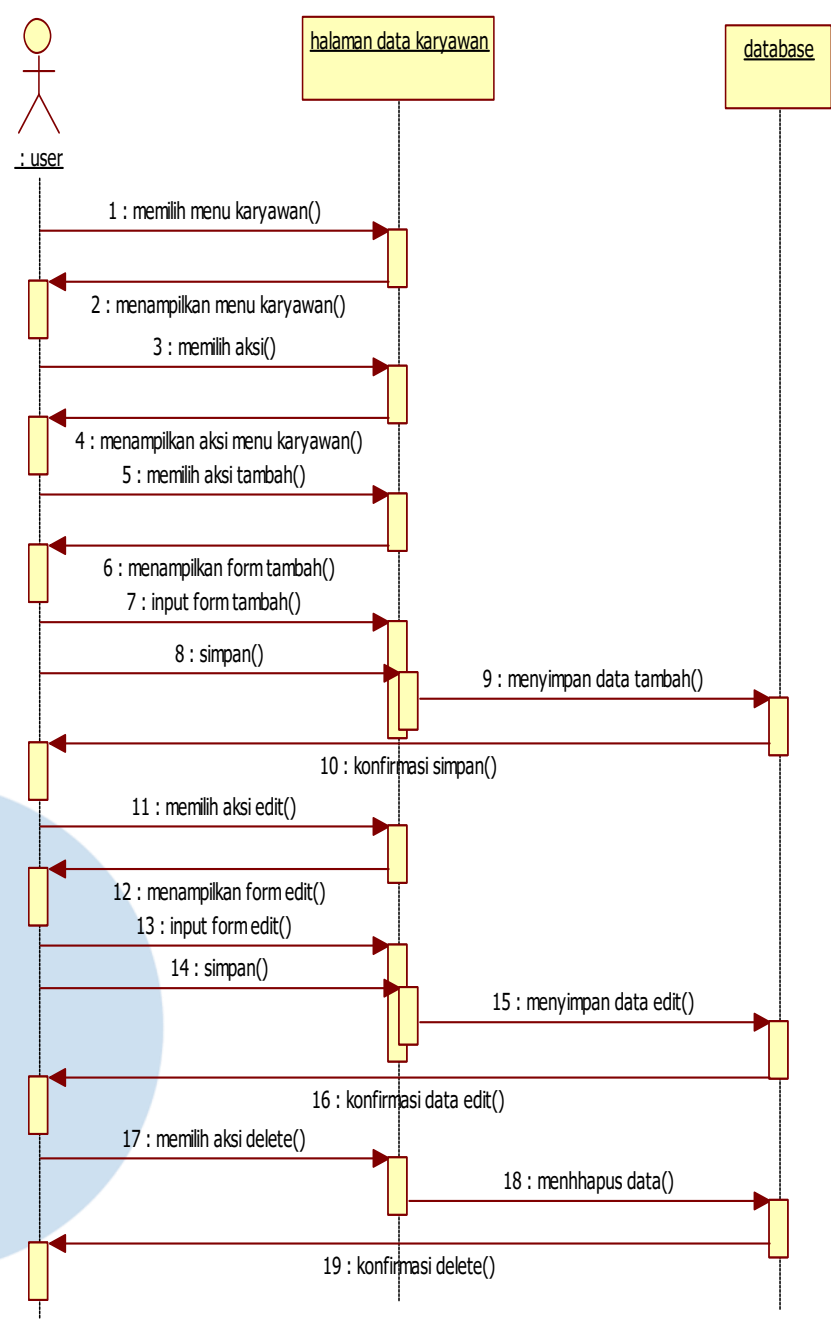

Gambar 5. Sequence diagram data karyawan

Sequence diagram data kriteria interaksi pengguna dan sistem pada halaman data kriteria. Urutan kerja yang dilakukan oleh User dalam mengelola profile karyawan. iUser yang telah berhasil masuk ke dalam halaman utama dapat memilih aksi tambah, edit, dan delete. Setelah dipilih aksi tambah dan edit, sistem akan menampilkan tampilan form untuk tambah dan edit. Form pada input tambah dan edit yang berisikan form data karyawan yang harus diisi oleh User. Setelah diisi dengan benar, data disimpan. User memilih aksi delete maka data kriteria akan terhapus. Sequence Diagram kelola data kriteria dapat dilihat pada Gambar 6. 


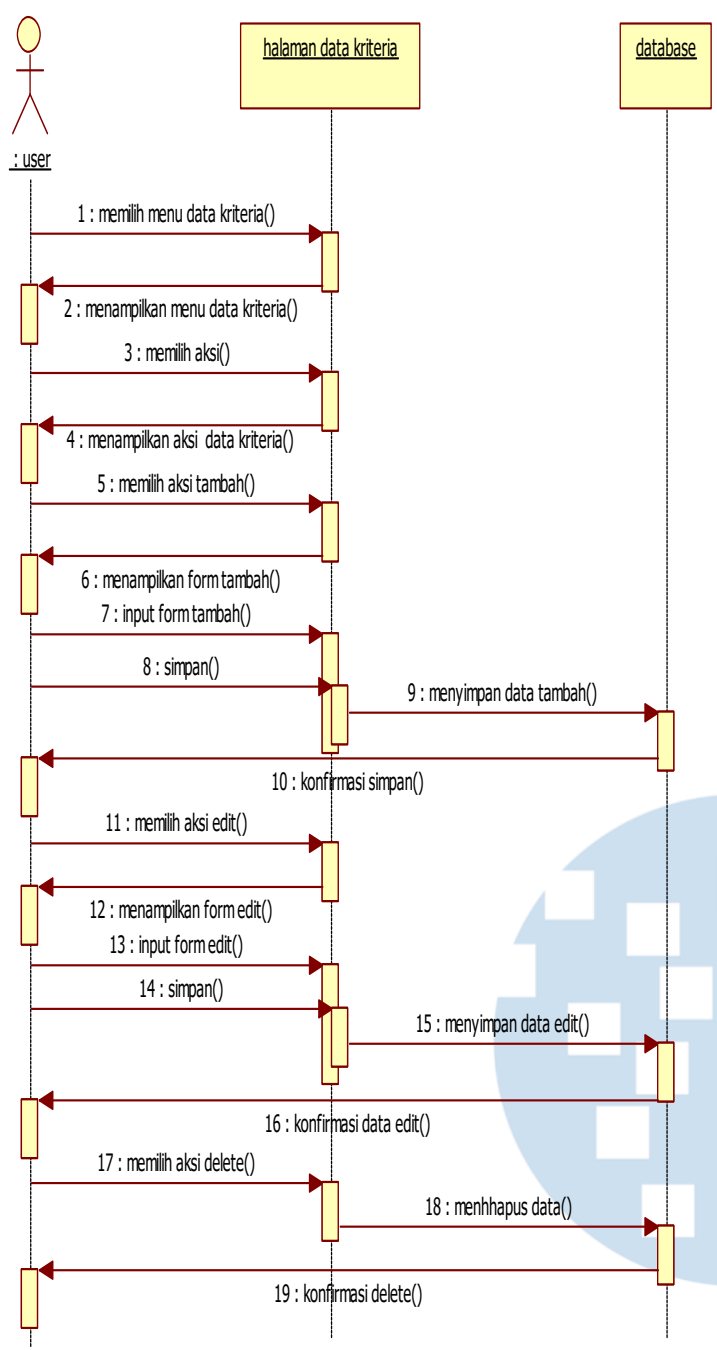

Gambar 6. Sequence diagram data kriteria

Sequence diagram data jabatan menggambarkan interaksi pengguna dan sistem pada halaman data jabatan. Urutan kerja yang dilakukan oleh User dalam mengelola profile karyawan. User yang telah berhasil masuk ke dalam halaman utama dapat memilih aksi tambah, edit, dan delete. Setelah dipilih aksi tambah dan edit, sistem menampilkan tampilan form untuk tambah dan edit. Form pada input tambah dan edit yang berisikan form data karyawan yang harus diisi oleh User. Setela diisi dengan benar, data disimpan. User memilih aksi delete makal data jabatan akan terhapus. Sequence Diagram kelola data jabatan dapat dilihat seperti Gambar 7.

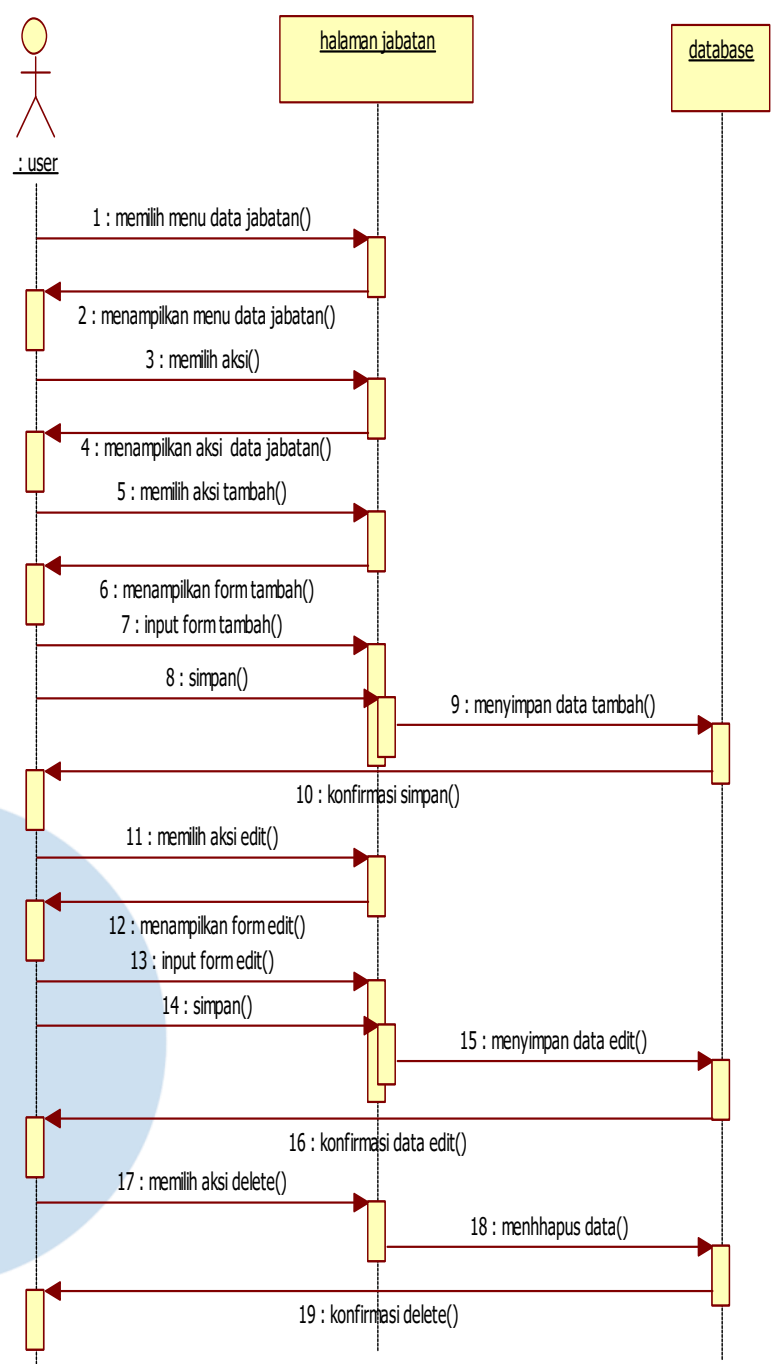

Gambar 7. Sequence diagram data jabatan

\section{Class Diagram}

Class diagram menggambarkan struktur statis dari kelas dalam suatu sistem dan sehingga dapat menggambarkan atribut, operasi dan hubungan suatu antarkelas. Class diagram membantu dalam melakukan struktur class-class dari suatu sistem sehingga merupakan tipe diagram yang paling banyak dipakai. Class diagram pada sistem pendukung keputusan penyeleksian karyawan baru pada PT. Dinasti Motekar Group disajikan pada Gambar 8. 


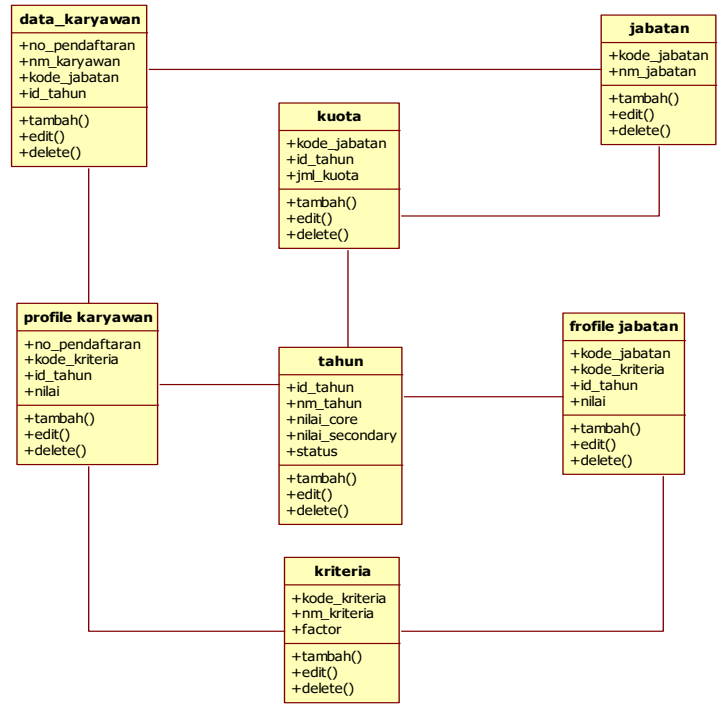

Gambar 8. Class diagram

\section{Implementasi Sistem}

Sistem informasi ini diimplementasikan dengan menggunakan bahasa pemrograman PHP. Dari setiap sistem yang telah dirancang memerlukan suatu sarana pendukung diantaranya adalah software dan hardware yang menunjang dalam penerapan sistem. Hasil implementasi dapat dilihat pada gambar berikut.

\section{Form Data Karyawan}

Untuk melakukan penilaian terhadap sistem maka sebelumnya pengguna menginput data profil karyawan. Untuk proses data profil karyawan seperti Gambar 9.

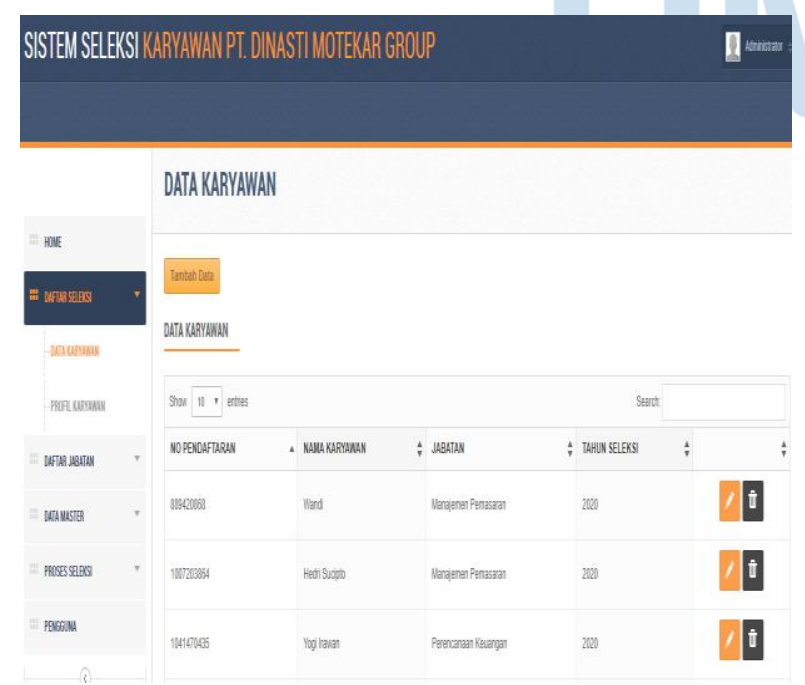

Gambar 9. Form data karyawan

\section{Form Profil Karyawan}

Untuk melakukan penilaian terhadap sistem maka sebelumnya pengguna menginput data profil jabatan. Untuk proses data profil jabatan seperti Gambar 10.
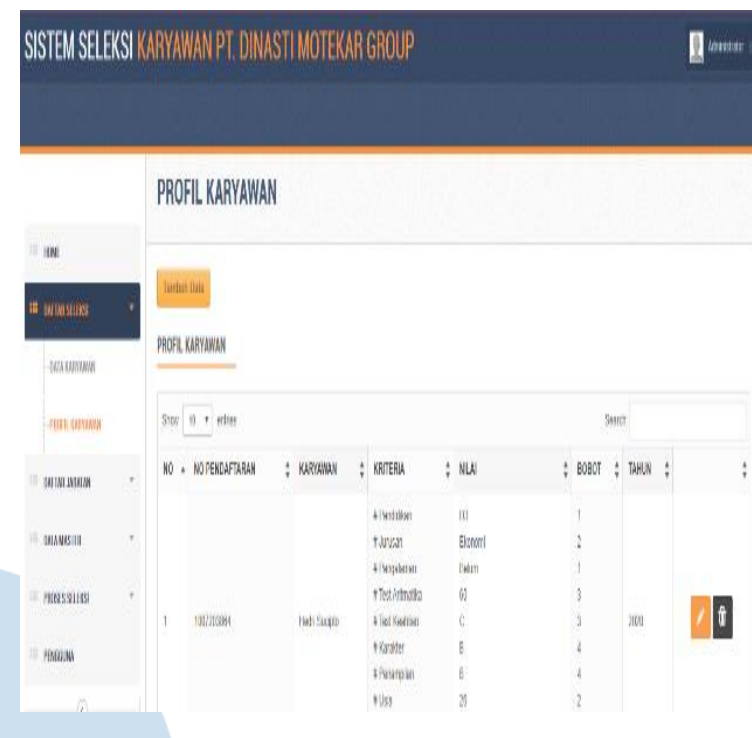

Gambar 10. Form profil karyawan

3. Form Data Jabatan

Sebelum melakukan penilaian terhadap sistem perekrutan karyawan maka pengguna akan mengecek data jabatan seperti pada Gambar 11.
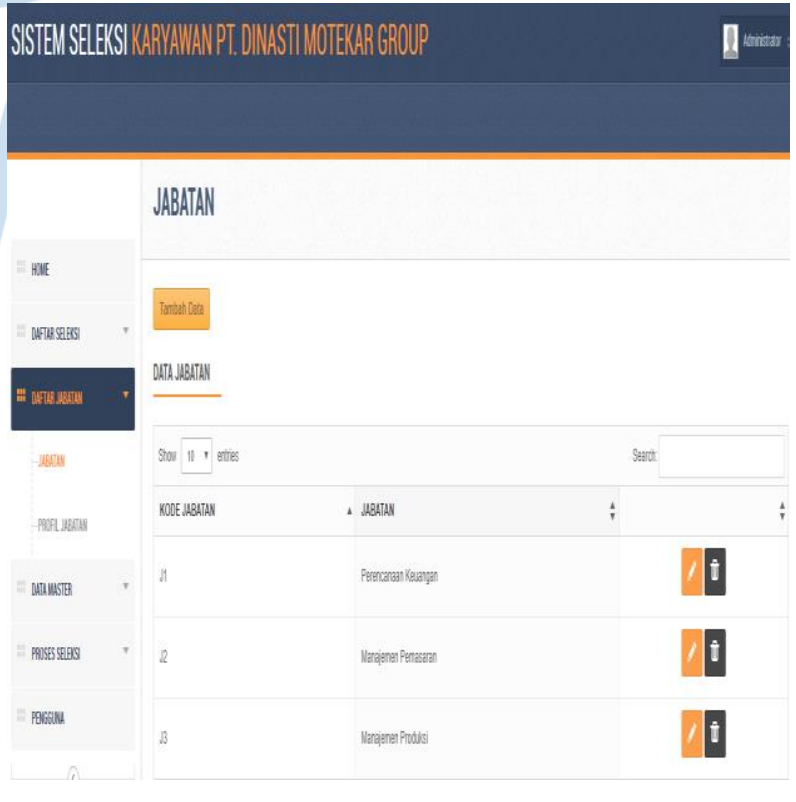

Gambar 11. Form data jabatan

4. Form Profil Jabatan 
Untuk melakukan penilaian terhadap sistem maka sebelumnya pengguna menginput data profil jabatan seperti pada Gambar 12.
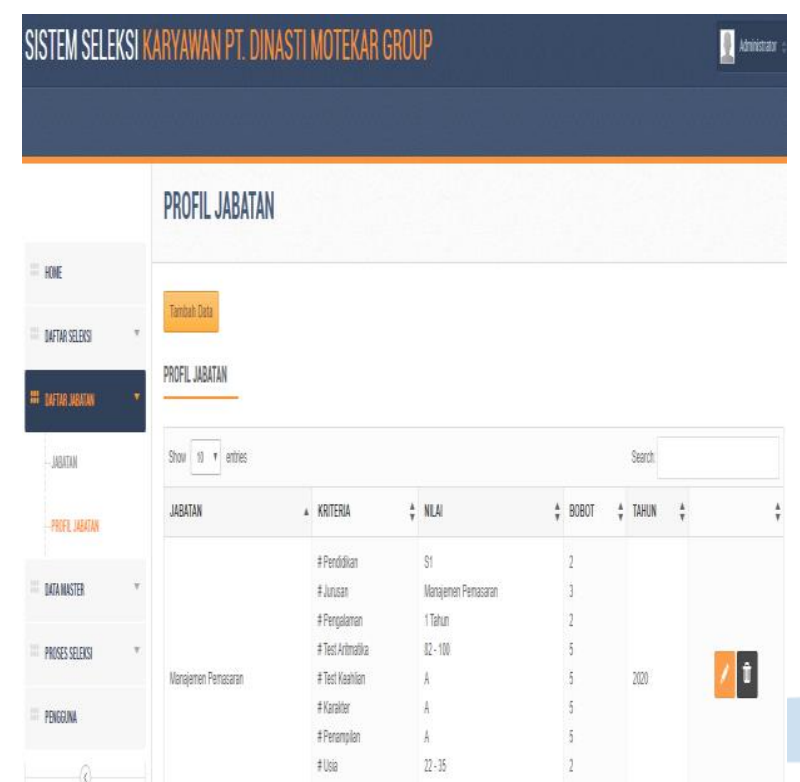

Gambar 12. Form profil jabatan

\section{Form Data Kriteria}

Untuk melakukan penilaian terhadap sistem maka sebelumnya pengguna telah menginput data-data kriteria yang telah ditentukan oleh perusahaan seperti pada Gambar 13.
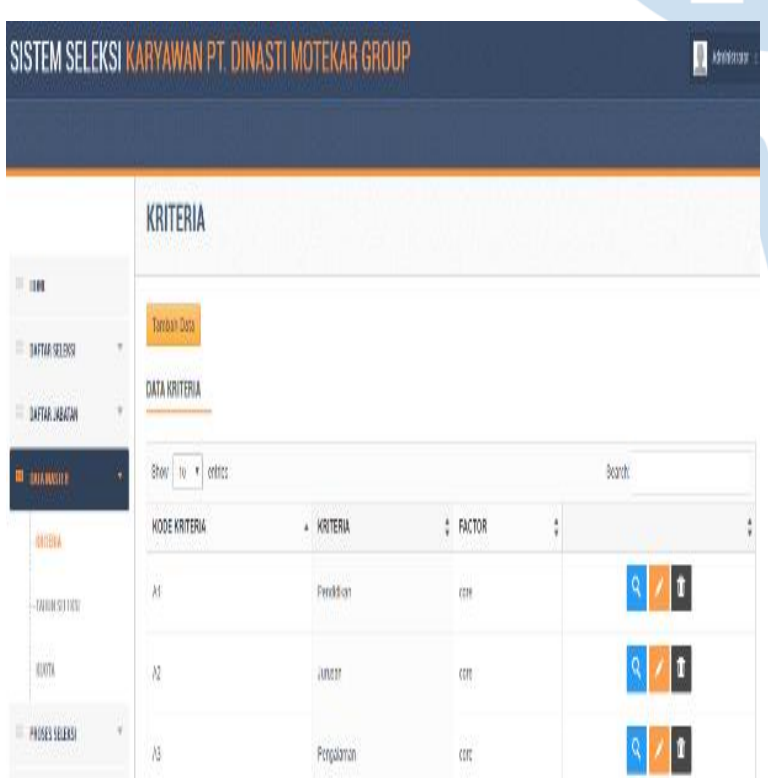

Gambar 13. Form profil kriteria

\section{Form Seleksi}

Berikut adalah menu seleksi yang berisi proses perhitungan profile matching pada sistem perekrutan karyawan seperti pada Gambar 14.
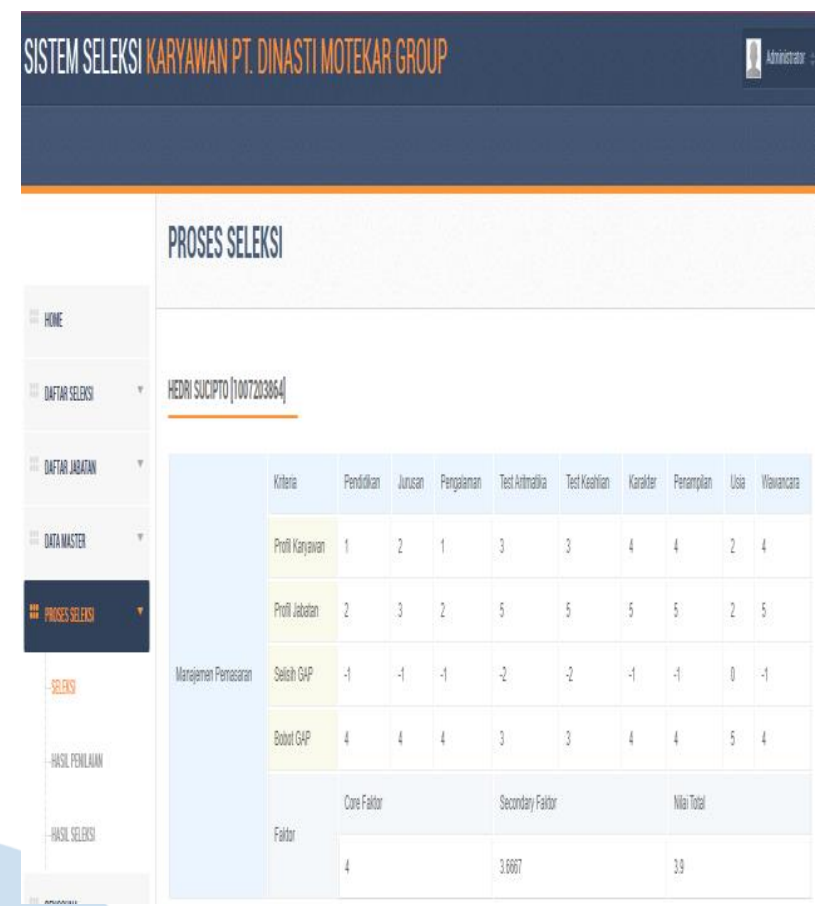

Gambar 14. Form seleksi

7. Form Hasil Seleksi

Berikut ini adalah menu hasil seleksi karyawan, pada menu ini berisi hasil akhir dari perhitungan dan memberikan hasil yang sesuai kuota jabatan yang telah di tentukan perusahaan seperti pada Gambar 15.
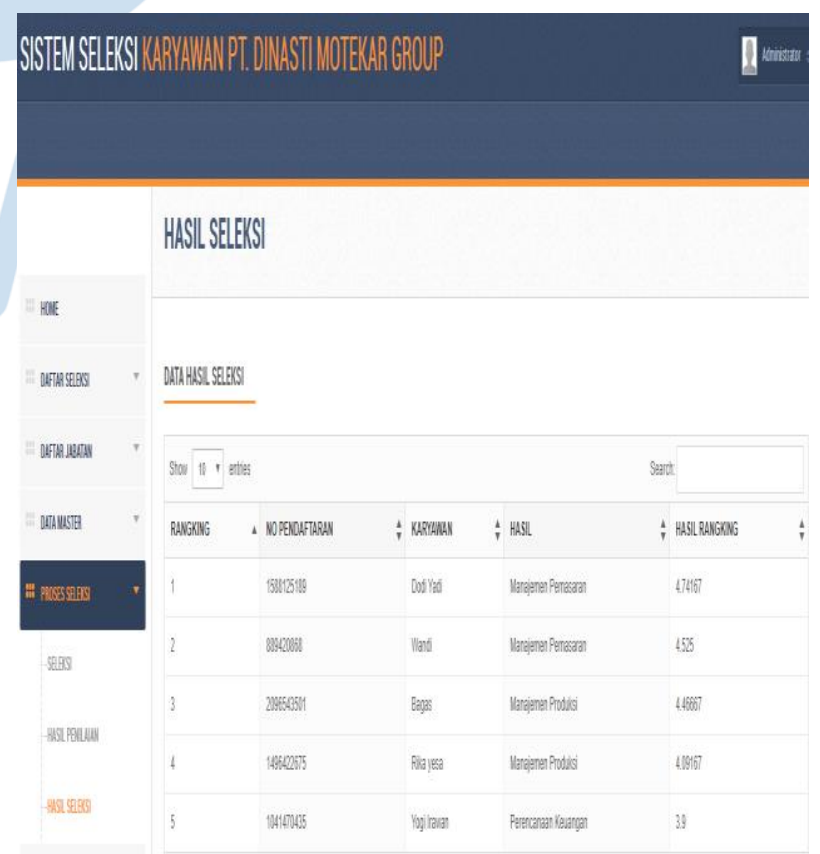

Gambar 15. Form hasil seleksi 
Ranking adalah hasil akhir dari metode Profile Matching yang ditampilkan pada aplikasi bagian Tampilkan Data. Hasil tersebut diolah saat pengguna mengisi atau mengubah data, lalu disimpan ke dalam database. Diterima karyawan yang dimaksud adalah karyawan yang mendapatkan ragking tertinggi dari kuota yang diadakan oleh pihak perusahaan. Berikut adalah hasil yang diproses oleh aplikasi.

Tabel 10. Hasil dari pengujian

\begin{tabular}{|c|c|c|c|c|}
\hline $\begin{array}{c}\text { No. } \\
\text { Pendaftaran }\end{array}$ & Karyawan & Jabatan & Nilai & Ranking \\
\hline 1588125189 & Dodi Yadi & $\begin{array}{c}\text { Manajemen } \\
\text { Pemasaran }\end{array}$ & 4.74 & 1 \\
\hline 889420858 & Mardi & $\begin{array}{c}\text { Manajemen } \\
\text { Pemasaran }\end{array}$ & 4.52 & 2 \\
\hline 2095543501 & Bagas & $\begin{array}{c}\text { Manajemen } \\
\text { Produksi }\end{array}$ & 4.45 & 1 \\
\hline 149542275 & Rika Jesa & $\begin{array}{c}\text { Manajemen } \\
\text { Produksi }\end{array}$ & 4.09 & 2 \\
\hline 1041470435 & $\begin{array}{c}\text { Yogi } \\
\text { Irawan }\end{array}$ & $\begin{array}{c}\text { Perencanaan } \\
\text { Karyawan }\end{array}$ & 3.9 & 1 \\
\hline
\end{tabular}

Hasil rangking karyawan Tabel 10 menunjukkan Bahwa nilai tertinggilah yang dapat bekerja diperusahaan yang berdasarkan kuota setiap jabatan.

\section{Pengujian Sistem}

Setelah tahap implementasi dilakukan maka akan diuat pengujian pada sistem. Pada tahap pengujian dilakukan ingin mengetahui apakah sistem tersebut layak digunakan pada pengguna. Pada pengujian ini akan dilakukan pengujian pada sistem seleksi karyawan menggunakan pengujian Black Box seperti Tabel 11.

Tabel 11. Pengujian sistem

\begin{tabular}{|c|c|c|c|}
\hline No. & $\begin{array}{c}\text { Item } \\
\text { Uji }\end{array}$ & $\begin{array}{c}\text { Detail } \\
\text { Pengujian }\end{array}$ & Hasil \\
\hline 1 & Autentikasi & Login, Logout & Sesuai \\
\hline 2 & $\begin{array}{c}\text { Kelola Data } \\
\text { Karyawan }\end{array}$ & $\begin{array}{c}\text { Lihat, Tambah, Edit, } \\
\text { Delete }\end{array}$ & Sesuai \\
\hline 3 & $\begin{array}{c}\text { Kelola Data Profil } \\
\text { Karyawan }\end{array}$ & $\begin{array}{c}\text { Lihat, Tambah, Edit, } \\
\text { Delete }\end{array}$ & Sesuai \\
\hline 4 & $\begin{array}{c}\text { Kelola Data Profil } \\
\text { Jabatan }\end{array}$ & $\begin{array}{c}\text { Lihat, Tambah, Edit, } \\
\text { Delete }\end{array}$ & Sesuai \\
\hline 5 & Kelola Data Jabatan & $\begin{array}{c}\text { Lihat, Tambah, Edit, } \\
\text { Delete }\end{array}$ & Sesuai \\
\hline 6 & Kelola Data Kriteria & $\begin{array}{c}\text { Lihat, Tambah, Edit, } \\
\text { Delete }\end{array}$ & Sesuai \\
\hline 7 & Kelola Data Kuota & $\begin{array}{c}\text { Lihat, Tambah, Edit, } \\
\text { Delete }\end{array}$ & Sesuai \\
\hline 8 & Kelola Data Tahun & $\begin{array}{c}\text { Lihat, Tambah, Edit, } \\
\text { Delete }\end{array}$ & Sesuai \\
\hline 9 & Kelola Seleksi & Lihat & Sesuai \\
\hline 10 & Kelola Hasil & Lihat & Sesuai \\
\hline 11 & Kenilaian & Lihat & Sesuai \\
\hline
\end{tabular}

\section{KESIMPULAN}

Sistem Pendukung Keputusan perekrutan karyawan Pada PT. Dinasti Motekar Group, telah berhasil dibangun menggunakan metode Profile Matching Dan perancangan menggunakan metode
Rational Unified Proces (RUP). Dari hasil pengujian yang dilakukan terhadap sistem ini menunjukkan bahwa sistem yang dibangun telah sesuai dengan kebutuhan yang dibutuhkan oleh pihak perusahaan dalam melakukan perekrutan karyawan Sistem Pendukung Keputusan perekrutan karyawan ini masih membutuhkan pengembangan lebih lanjut yang sesuai dengan dikembangkan lagi agar kinerja sistem menjadi lebih baik diharapkan aplikasi ini dapat dikembangkan dengan menambah fungsi-fungsi yang lebih. Pada pengujian yang telah dilakukan oleh sembilan pengguna terhadap Sistem Pendukung Keputusan perekrutan karyawan berbasis web Pada PT. Dinasti Motekar Group, diperoleh hasil bahwa sistem yang telah dibangun berjalan dengan baik rancangan yang dibuat.

\section{DAFTAR PUSTAKA}

[1] Sondang P. Siagian, Manajemen Sumber Daya Manusia, (Jakarta: PT Bumi Aksara, 2015), hlm.131.

[2] Dha E. Turban, R. Sharda dan D. Delen, Decision Support and Business Intelligence Systems, 2011: Pearsson, New Jersey.

[3] F. and S. D. H. Permana, "Sistem Penunjang Keputusan Pemilihan Sekolah Menengah Kejuruan Teknik Komputer Dan Jaringan Yang Terfavorit Dengan Menggunakan MultiCriteria Decision Making," J. Teknol. Inf. dan Ilmu Komput., vol. 2, no. 1, p. 11, 2015, doi: 10.25126/jtiik.201521123.

[4] E. Turban, J. E. Aronson, and T.-P. Liang, "Decision Support Systems and Intelligent Systems (Edisi Bahasa Indonesia).” p. 697, 2005.

[5] Sianturi, Fricles Ariwisanto. 2015. Implementasi Sistem Pendukung Keputusan Kenaikan Jabatan Guru Dengan Model Profile Matching Pada Sekolah SMA Swasta Raksana Medan. ISSN: 2088-3943. Medan: Jurnal Mantik Penusa Vol. 18, No.2 Desember 2015: 44-52.

[6] W. Setiyaningsih. Decision Support System Menggunakan Metode Profile Matching. 2013. URL: http://staff.budiluhur.ac.id/deni.mahdiana/files/2013/05/Meto de-Profile-Matching.pdf, diakses tanggal 3 Maret 2016.

[7] Juanita, 2015, Sistem Pendukung Keputusan Penentuan Warga Miskin dengan Metode Simple Additive Weighing (SAW) dan Profile Matching, Universitas Sumatera Utara, Medan.

[8] A.S Rosa , dan M.Shalahuddin. 2014. Rekayasa Perangkat Lunak Struktur dan Berorientasi Objek. Bandung : Informatika.

[9] Heriyanto, Y. (2018). Perancangan Sistem Informasi Rental Mobil Berbasis Web Pada PT.APM Rent Car. Jurnal IntraTech, 2(2), 64-77.

[10] R. S. Pressman, Rekayasa Perangkat Lunak: Pendekatan Praktisi Buku I. Yogyakarta: ANDI, 2015.

[11] Gata, Windu dan Gata, Grace. (2013). Sukses Membangun Aplikasi Penjualan dengan Java. Jakarta : Elex Media Komputindo.

[12] D. Wira, T. Putra, and R. Andriani, "Unified Modelling Language ( UML ) dalam Perancangan Sistem Informasi Permohonan Pembayaran Restitusi SPPD," vol. 7, no. 1, 2019.

[13] Samsoni, "Perancangan Sistem Informasi Kontrol Produksi Sepatu (Studi Kasus: PT. Asia Dwimitra Industri Tangerang)," J. Inform. Univ. Pamulang, vol. 2, no. 3, pp. 153-158, 2017, [Online]. Available: http://openjournal.unpam.ac.id/index.php/informatika/article/ view/1445/pdf. 
[14] Sugiyono.(2013). Metode Penelitian Kuantitatif, Kualitatif dan R\&D. Bandung:

[15] Haviluddin, "Memahami Penggunaan UML ( Unified Modelling Language )," Memahami Pengguna. UML (Unified
Model. Lang., vol. 6, no. 1, pp. 1-15, 2011, [Online]. Available:

https://informatikamulawarman.files.wordpress.com/2011/10/

01-jurnal-informatika-mulawarman-feb-2011.pdf. 